\title{
Elaboration and Performance Analysis of a Bio-Based Insulating Liquid from Castor Oil for Power Transformers
}

\author{
Emeric Tchamdjio Nkouetcha*, Ghislain Mengata Mengounou, Adolphe Moukengue Imano \\ Laboratory of Technology and Applied Sciences, University of Douala, Douala, Cameroon \\ Email: ${ }^{\star}$ tchamdjio@univ-douala.com
}

How to cite this paper: Nkouetcha, E.T., Mengounou, G.M. and Imano, A.M. (2019) Elaboration and Performance Analysis of a Bio-Based Insulating Liquid from Castor Oil for Power Transformers. Open Access Library Journal, 6: e5404.

https://doi.org/10.4236/oalib.1105404

Received: April 15, 2019

Accepted: May 12, 2019

Published: May 15, 2019

Copyright () 2019 by author(s) and Open Access Library Inc.

This work is licensed under the Creative Commons Attribution International License (CC BY 4.0).

http://creativecommons.org/licenses/by/4.0/

\begin{abstract}
The research for new mineral oil substitutes focuses on vegetable oils known for their biodegradability and low toxicity. This paper focuses on the development and analysis of physicochemical and dielectric properties of a bio-based insulating liquid from castor oil. Castor oil is an inedible tropical resource. It has a good annual oil yield and is widely available in developing countries. Cold pressing of castor seeds is the most appropriate non-chemical process for extracting oil. A refining process was used to remove metal and chemical residues. Refined Castor Oil was filtered and degassed in order to minimize the dissolved gases, solid particles and moisture. A transesterification operation was performed to significantly reduce viscosity oil. Finally, obtained Castor Oil Methyl Esters (COME) are finally distilled in a rotary evaporator under vacuum to remove traces of water and methanol. Physicochemical properties as visual examination, relative density, kinematic viscosity, and acidity were measured in accordance with ASTM D6871. AC Breakdown voltage was performed according to IEC 60156, and had been analyzed using Weibull distribution. Processed Castor Oil (PCO) has low viscosity than certified transformer vegetable oils (BIOTEMP, FR3) and high Dielectric Strength (74.67 $\mathrm{kV} / 2.5 \mathrm{~mm}$ ). Partial Discharges characteristics including the Partial Discharge Inception Voltage and the Partial Discharge Propagation Voltage were also investigated according to the recommendations of IEC 61294. PCO has satisfactory properties for their use as an insulating oil for transformer.
\end{abstract}

\section{Subject Areas}

Chemical Engineering \& Technology, Electric Engineering

\section{Keywords}

Breakdown Voltage, Electric Strength, Transesterification, Partial Discharge, 
Castor Oil Methyl Esters, Vegetable Transformer Oil

\section{Introduction}

Transformer oil acts as coolant, insulation and maintenance indicator [1]. Mineral oil, derived from petroleum resources, is the most used in oil filled transformers. It benefits from a feedback of more than one hundred years. It has good oxidation stability, high dielectric strength $(>50 \mathrm{kV} / 2.5 \mathrm{~mm})$, low kinematic viscosity $\left(<11 \mathrm{~mm}^{2} / \mathrm{s} @ 40^{\circ} \mathrm{C}\right)$ and a low pour point $\left(\approx-60^{\circ} \mathrm{C}\right)[2]$. Nevertheless, it has a low fire resistance. In addition, it is toxic, non-renewable and non-biodegradable ( $<30 \%$ in 21 days). It is therefore dangerous close to risk areas such as hospitals or residences. Its cost has increased significantly over the last 20 years. Like mineral oil, other oils such as silicone oils or synthetic esters have good characteristics, but are non-renewable, poorly biodegradable and their high cost restricted their use to particular applications [3] [4]; they are therefore not considered as an alternative to mineral oils. All these new constraints have motivated the development for several years of better substitute oils to replace the mineral oils traditionally used, which are not able to provide adequate safety conditions. The arrival of vegetable oils or so-called "natural esters" on the market offers a solution to this problem.

As early as September 1999, the first commercial plant-based insulating oils, such as BIOTEMP ${ }^{\circledR}$ and Envirotemp ${ }^{\circledR} \mathrm{FR}^{\circledR}{ }^{\circledR}$ are developed and patented in the United States [5]. This has had the merit of reviving research on the use of natural esters as substitutes for mineral oil in high-power transformers. However, most of the plant resources investigated come from edible oils.

Recently, researchers investigated inedible oil-based insulating fluids. Abdelmalik [6] showed that methyl esters of Palm Kernel Oil have the specific thermal capacities equivalent to those of mineral oils. The experimental analysis carried out by Sitorus et al. revealed that the partial discharge characteristics of Jatropha Oil Methyl Esters and mineral oil are close [7]. Mengounou et al. [8] analyzed the physicochemical properties of Palm Kernel Oil Methyl Esters and found that their properties were comparable to those of the patented insulating vegetable oils. Mariprasath et al. found that the breakdown voltage of the insulating oil based on Pongamia Pinnata seeds was greater than that of mineral oil; in addition, the moisture content decreases with aging of the oil [9]. The investigations conducted by Umal et al. on Neem Oil Epoxy Methyl Esters showed that its dielectric losses are in the dielectric loss range of the bio-based insulating oils [10]. According to the work of Ravulapalli et al., the dielectric losses and the volume resistivity of Methyl Ester of Sesbania Seeds oil are higher than those of mineral oil [11].

The present investigation focuses on castor oil. It is an inedible oil and widely available in Cameroon. Crude castor oil does not meet specifications for bio-based insulating fluids. A treatment is therefore necessary. The first objective of this 
study is to present a crude oil exaction method which provides a good yield and a quality oil, and a processing oil method. The second objective is to analyze physicochemical and dielectric characteristics of processed castor oil with respect to standards for insulating vegetable oils.

\section{Materials and Methods}

\subsection{Presentation of Castor Oil}

Castor oil plant (Ricinus communis) is a shrubby plant (Figure 1(a)) grown mainly in tropical climates. India, Brazil and China are the main producers, with 1630,170 and 62 kilotons respectively of seeds according to the 2012 FAOStat database. Depending on the variety, the castor seed varies between $0.3 \mathrm{~g}$ and 0.5 $\mathrm{g}$ for a length of between $10.6 \mathrm{~mm}$ and $23.5 \mathrm{~mm}$, a width varying from $6.7 \mathrm{~mm}$ to $14.7 \mathrm{~mm}$ and a thickness ranging from $4.7 \mathrm{~mm}$ to $8.3 \mathrm{~mm}$. The oil content varies in proportion to the amount of heat received by the plant and is around $48 \%$ [12]. It is very rich in ricinoleic acid (just over $85 \%$ ). The non-edibility of castor bean is due to the presence of several toxic components. The oil only has a laxative effect, but the cake from the extraction contains a highly toxic protein called ricin, less toxic ricinin and ricinididine and finally an allergen called CB-1A [13]. After extraction, all these toxic substances remain in the cake. The harvest is essentially manual. The still green fruits (Figure 1(b)) are torn off and dried (Figure 1(c)) in the sun inside a large container. After several days, castor shells burst to release the seeds (Figure 1(d)). The yield obtained is of the order of 500 to $800 \mathrm{~kg}$ of oil/ha [13].

\subsection{Extraction of Castor Oil}

The seeds were obtained from local production in the city of Douala (Cameroon). There are several methods of extracting castor oil: traditional extraction, expeller pressing, hydraulic pressing and solvent extraction. The expeller pressing process is widely used in the food industry. Extraction yield is high but the cost of acquisition of the expeller press remains very high compared to the

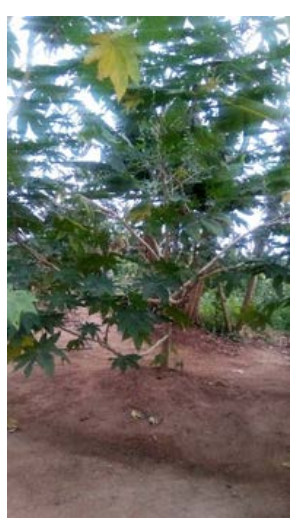

(a)

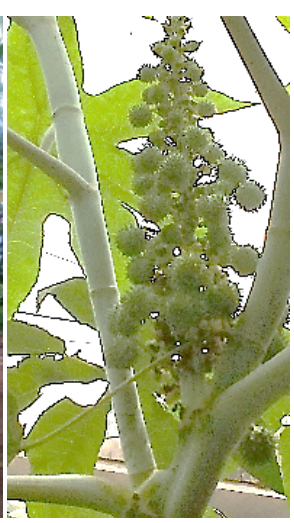

(b)

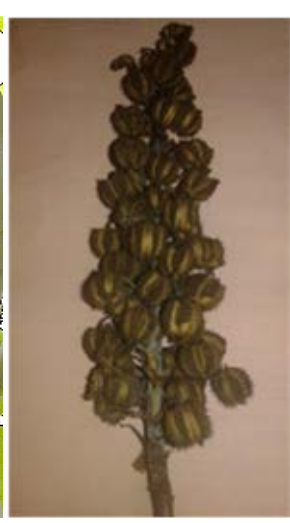

(c)

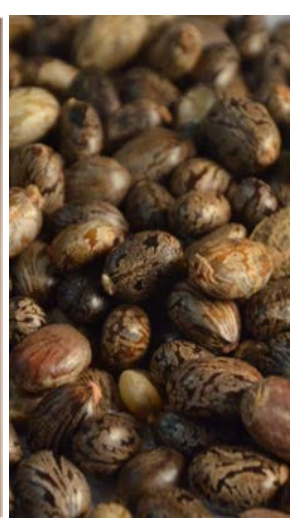

(d)

Figure 1. Ricinus communis. (a) The plant; (b) Green fruits; (c) Dried fruits; (d) Seeds obtained after shucking. 
hydraulic press. Solvent extraction method is a more expensive method. It is mainly used in the laboratory and is therefore not suitable for industry level.

In this paper, two conventional extraction methods that can be easily used in rural areas have been investigated: traditional extraction and mechanical extraction using hydraulic press.

\subsubsection{Traditional Extraction of Castor Oil}

Traditional extraction (Method A) is a hot extraction method (Figure 2). The seeds are shelled and then cooked in water at a temperature of about $90^{\circ} \mathrm{C}$ for 15 minutes. The seeds are then sun dried and crushed. The resulting paste $(1 \mathrm{~kg})$ is mixed with 2 liters of water and the whole is heated. The castor oil, supernatant, is recovered by means of a dipper and then dehydrated.

\subsubsection{Hydraulic Extraction of Castor Oil}

The mechanical extraction of the castor oil was carried out by means of a 10 tons' hydraulic press. Two methods were investigated: hot extraction and cold extraction. Hot extraction (Method B) involves heating the castor seeds in the oven at a temperature of $60^{\circ} \mathrm{C}$. The seeds are then crushed using a manual mill and introduced into the hydraulic press. Regarding cold extraction, two techniques are presented. The first (Method C) is to grind and squeeze the shelled seeds without preheating. The second (Method D) is to make a paste of castor seeds unshelled, discarding the teeth of the mill about $2 \mathrm{~mm}$. The paste obtained is pressed by means of the hydraulic press. Then the resulting cake undergoes a fine grinding and is reintroduced into the press. Figure 3 summarizes the three investigated methods of mechanical extraction of castor oil. Extraction rate is compute using Equation (1):

$$
\eta=\frac{\text { weight }_{\text {oil }}}{\text { weight }_{\text {seed }}}
$$

\subsection{Refining Castor Oil}

The refining of castor oil has been adapted to industry standards for the refining of edible oils in accordance with ASTM D6871 [14]. The refining process is shown in Figure 4.

\subsubsection{Water Degumming}

The purpose of the degumming is to extract the substances contained in the

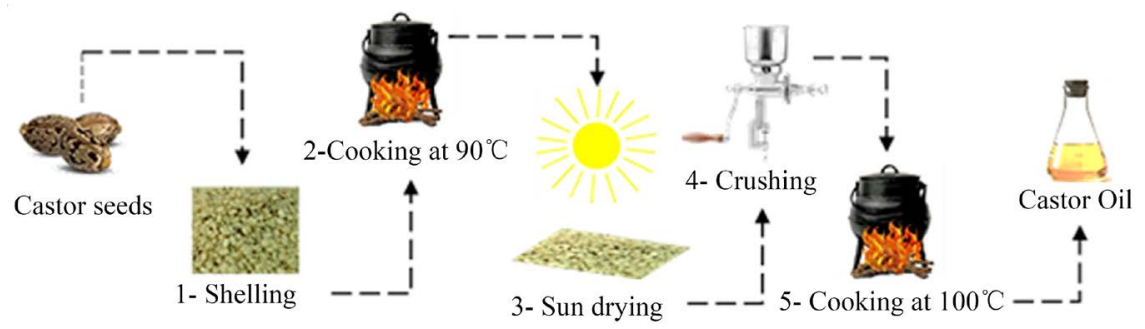

Figure 2. Traditional extraction process of castor oil. 


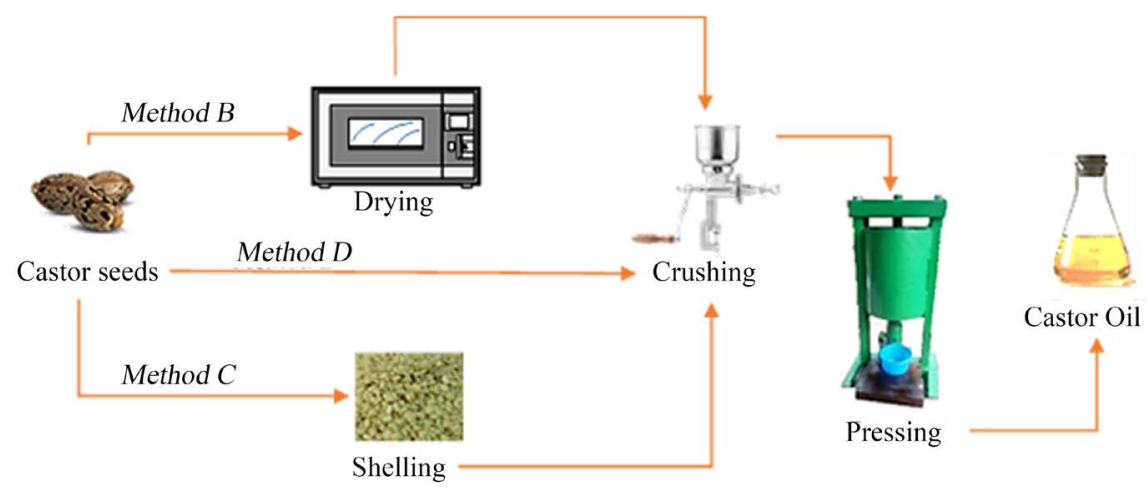

Figure 3. Hydraulic extraction process of castor oil.

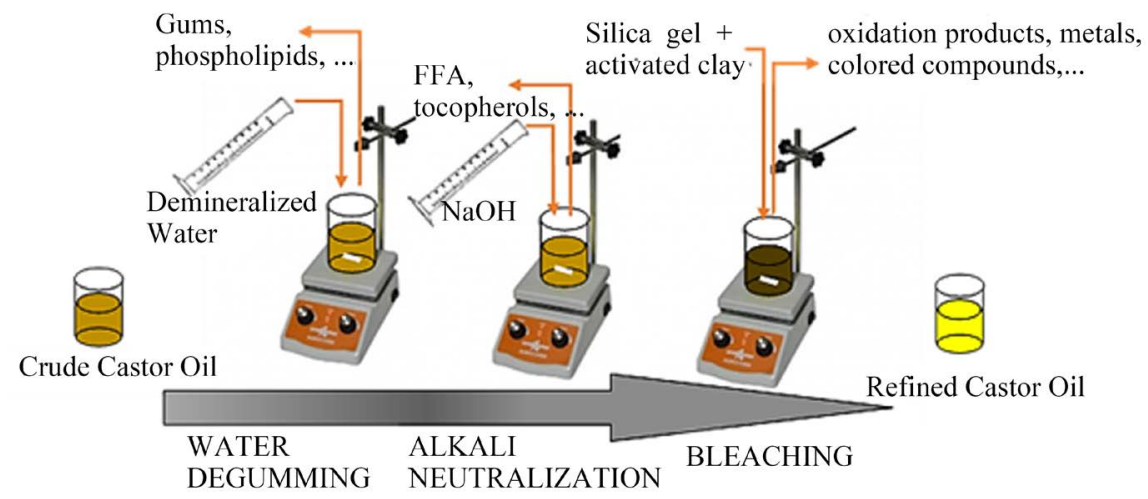

Figure 4. Castor oil refining process.

crude oil that may become insoluble by hydration, such as gums and phospholipids. The crude oil is obtained by cold pressing of unshelled seeds. The demineralized water (20 wt\%) is heated to $90^{\circ} \mathrm{C}$ and added to the crude oil. The whole is slowly mixed at $30 \mathrm{rpm}$ for 40 minutes. The degummed oil is recovered by means of a centrifuge.

\subsubsection{Alkaline Neutralization and Washing}

Neutralization reduces or eliminates impurities (free fatty acid (FFA), phospholipids, tocopherols, colored compounds...) from the degummed oil. It consists in mixing with the crude oil a solution of soda to transform the free fatty acids into soaps. A soda solution at $10^{\circ} \mathrm{Be}$ is prepared and added to the degummed castor oil at room temperature and low stirring speed to avoid emulsion. The mixture is then stirred at $60 \mathrm{rpm}$ for 20 minutes at $90^{\circ} \mathrm{C}$. Then, hot deionized water $(15$ $w t \%)$ is added to the mixture. The stirring speed is increased to $90 \mathrm{rpm}$ for better soap removal. The agitator is off and the soap in the oil is allowed to settle to the bottom of the beaker. The process of washing the water and draining the soap is done 3 times to ensure that a maximum amount of soap has been removed.

\subsubsection{Bleaching and Drying}

The purpose of bleaching is to remove oil pigments as well as primary and secondary oxidation products, metals, soaps, phosphatidic and polyaromatic com- 
pounds together with natural antioxidants (such as tocopherol) by an absorption process. The bleaching is carried out by introducing into the oil a mixture consisting of silica gel ( $1 \mathrm{wt} \%)$ and activated clay ( $5 \mathrm{wt} \%)$. The whole is stirred for 25 minutes under vacuum at $90^{\circ} \mathrm{C}$. The bleached oil is filtered (porosity $2 \mu \mathrm{m}$ ), dehumidified and degassed at $70^{\circ} \mathrm{C}$ for 4 hours to reduce the water content to less than $200 \mathrm{ppm}$ and the dissolved gas content.

\subsection{Transesterification Process of Castor Oil}

The transesterification of the oil was carried out with methanol $\left(\mathrm{CH}_{3} \mathrm{OH}\right)$ in the presence of potassium hydroxide $(\mathrm{KOH})$ as a catalyst (Figure 5). The transesterification process of Refined Castor Oil is illustrated in Figure 6. The molar ratio between oil and methanol is $1: 9$, while that of $\mathrm{KOH}$ is $1 \mathrm{wt} \%$ at room temperature. After the reaction, the mixture is poured into a separating funnel and allowed to stand for several hours. After decantation, the mixture is separated into two layers: Castor Oil Methyl Ester (COME) and glycerol. The resulting COME are washed with hot water $\left(90^{\circ} \mathrm{C}\right)$ to remove excess catalyst and unreacted methanol. The washing is repeated 4 times. COME are finally distilled in a rotary evaporator under vacuum at $70^{\circ} \mathrm{C}$ to remove traces of water and methanol. Finally, Processed Castor Oil (PCO) is filtered, dehumidified and degassed at $70^{\circ} \mathrm{C}$ for 12 hours as discussed in [1].

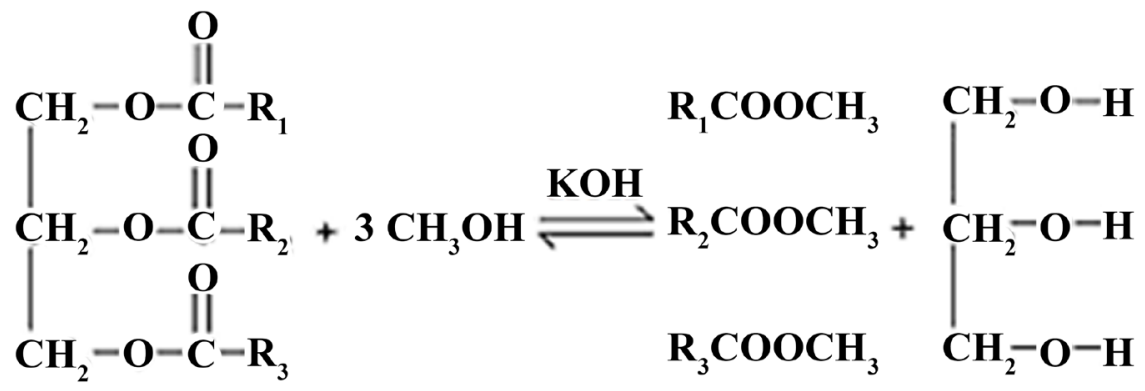
Triglycerides
Methanol
Methyl Esters
Glycerol

Figure 5. Transesterification reaction.

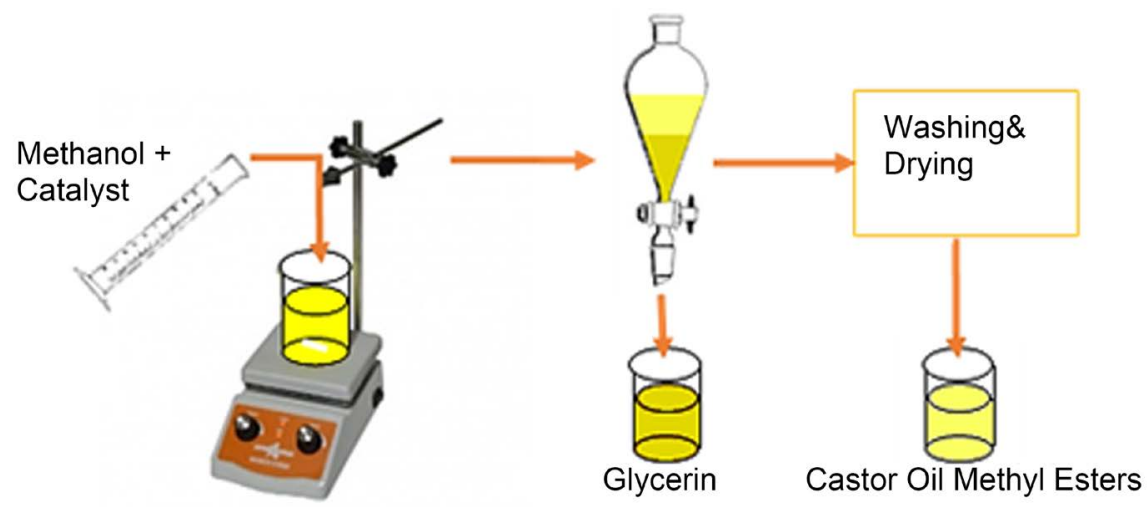

Figure 6. Castor oil transesterification process. 


\subsection{Physicochemical Characterization}

The physicochemical characterization of COME was performed with the requirements of ASTM D6871. Properties that have been investigated are color, viscosity, density, and Acid Number (AN).

\subsubsection{Color (ASTM D1500)}

The color is often used as a qualitative method. The technique is based on the comparison of oil color to a standard colored and numbered disc. An increasing or high color number is an indication of contamination, deterioration, or both [15]. It can see in Table 1 guideline for Quality Index Number (QIN) and eventual actions to be taken on the oil.

\subsubsection{Acidity Number (ASTM D974)}

During the degradation of the insulating oil, acids such as carboxylic acids are produced. The ANor acidity of the oil refers to the mass of a base in milligrams, in this case potassium hydroxide, necessary to neutralize the acid in one gram of the sample. It increases mainly as long as the oil oxidizes. ANmeasurement allows the monitoring of the oil oxidation process. The higher AN value, the greater the extent of oxidation and the sooner soluble and colloidal products will form. However, this method does not determine the exact nature of the acids in the sample and does not indicate their structure or aggressiveness. ASTM D6871 recommends that the acid value of natural esters be at most $0.06 \mathrm{mg} \mathrm{KOH} / \mathrm{g}$. It consists of the dissolution of PCO in neutralized hot ethanol, followed by the titration of FFA by means of potassium hydroxide in the presence of phenolphthalein (colored indicator). When all the free fatty acids are neutralized, the solution turns pink.

\subsubsection{Relative Density (ASTM D1217)}

The density of an oil characterizes the mass of oil per unit volume. Density is an intrinsic characteristic of oil. The density of PCO was carried out using a $0.01 \mathrm{~g}$ digital analytical balance, a $25 \mathrm{ml}$ pycnometer and a thermoregulated vessel. The density is determined from the weight of the oil introduced into the pycnometer

Table 1. Quality index number and effect of oil quality on transformer's condition [15].

\begin{tabular}{|c|c|c|c|c|c|c|}
\hline Good Oils & Proposition A Oils & Marginal Oils & Bad Oils & Very Bad Oil & Extremely Bad Oils & Disastrous Oils \\
\hline 1 & 2 & 3 & 4 & 5 & 6 & 7 \\
\hline Pale Yellow & Yellow & Bright Yellow & Amber & Brown & Dark Brown & Black \\
\hline \multicolumn{7}{|c|}{ Effect on transformer } \\
\hline $\begin{array}{l}\text { Proving these } \\
\text { functions } \\
\text { 1) Efficient cooling } \\
\text { 2) Preserving } \\
\text { insulation }\end{array}$ & $\begin{array}{l}\text { Polar compounds } \\
\text { (sludge) in solution } \\
\text { (products of oil } \\
\text { oxidation) causes the } \\
\text { drop in IFT }\end{array}$ & $\begin{array}{l}\text { Fatty acids coat the } \\
\text { windings. Sludges in } \\
\text { solution ready for } \\
\text { initial fall out. Sludge } \\
\text { in insulation voids } \\
\text { highly probable }\end{array}$ & $\begin{array}{l}\text { In almost } 100 \% \text { of the } \\
\text { transformers in this } \\
\text { range sludges are } \\
\text { s deposited on core and } \\
\text { coils. Sludges are first } \\
\text { deposited in fin areas. }\end{array}$ & $\begin{array}{l}\text { Deposited sludges } \\
\text { continue to oxidize } \\
\text { and harden. } \\
\text { Insulation shrinkage } \\
\text { is taking place. } \\
\text { Premature failure a } \\
\text { good possibility }\end{array}$ & $\begin{array}{l}\text { Sludges insulate } \\
\text { cooling fans, block } \\
\text { vents causing } \\
\text { higher operating } \\
\text { temperatures }\end{array}$ & $\begin{array}{l}\text { Vast quantities } \\
\text { of sludges may } \\
\text { require other } \\
\text { means than } \\
\text { desludging } \\
\text { procedures. }\end{array}$ \\
\hline
\end{tabular}


and the previously determined weight of water necessary to fill the pycnometer at the same temperature.

\subsubsection{Kinematic Viscosity (ASTM D445)}

Kinematic viscosity is defined as the resistance to flow of a liquid subjected to gravity. To ensure good cooling, the bioisolants must be of Newtonian type; their maximum viscosity at $40^{\circ} \mathrm{C}$ must be less than 50 cSt [14]. Kinematic viscosity was investigated using aUbbelohde glass capillary viscometer, a thermostatic water bath and a chronometer. The measurement principle relies on the evaluation of the time to make the meniscus of oil pass by gravity between two marks of the viscometer.

\subsection{Dielectric Strength}

The dielectric tests were carried out using a HYYJ-502 dielectrometer manufactured by Wuhan HuayingPowertech\& Science Co. It has a control unit, a variable voltage booster transformer variable from 0 to $100 \mathrm{kV}, 50 \mathrm{~Hz}$ with steps of 0.5 to $5 \mathrm{kV} / \mathrm{s}$, a Plexiglas test cell with a capacity of $400 \mathrm{ml}$ (Figure 7). The breakdown voltage analysis was performed according to IEC 60156 [16]. The test cell used is DieltestBaur Type $400 \mathrm{ml}$ volume. The electrode system consists of two VDE type electrodes with a diameter of $36 \mathrm{~mm}$, for a gap distance of $2.50 \pm$ $0.05 \mathrm{~mm}$. The cell and the electrodes are cleaned with a volatile solvent (methanol). Then the electrodes are polished with an abrasive cloth and then washed with hot water at $60^{\circ} \mathrm{C}$. Once the electrodes are assembled in the test cell, the whole is dried in an oven. A small amount of oil is used to flush the test cell. The operation is performed three times. Finally, the oil sample is then poured into the test cell slowly and then allowed to stand for 30 minutes. All measurements were performed at room temperature.

\subsection{Partial Discharge Inception Voltage (PDIV)}

Figure 8 outlines the device used for the analysis of Partial Discharge Initiation Voltage (TIDP) and Partial Discharge Propagation Voltage (TPDP) of COME.

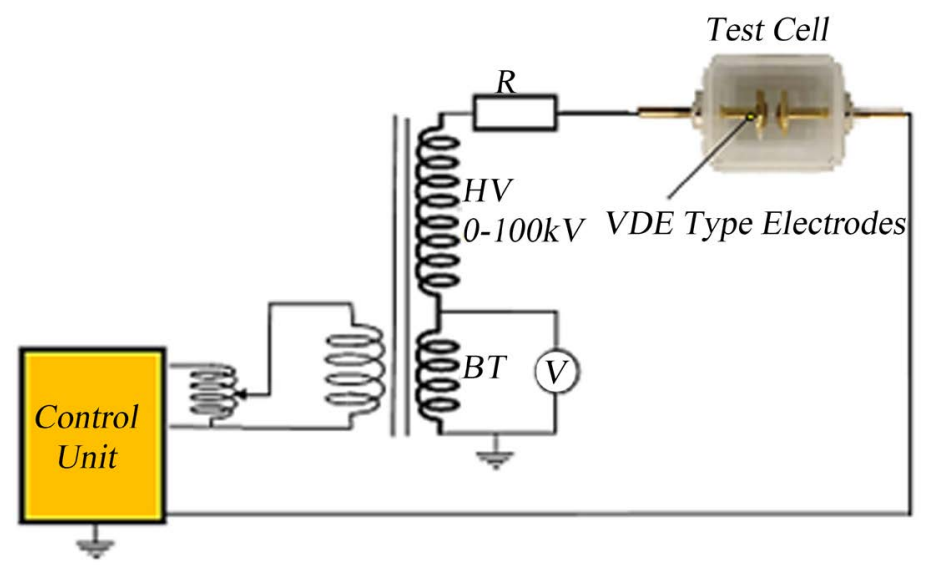

Figure 7. Schematic diagram of the HYYJ-502 dielectrometer. 


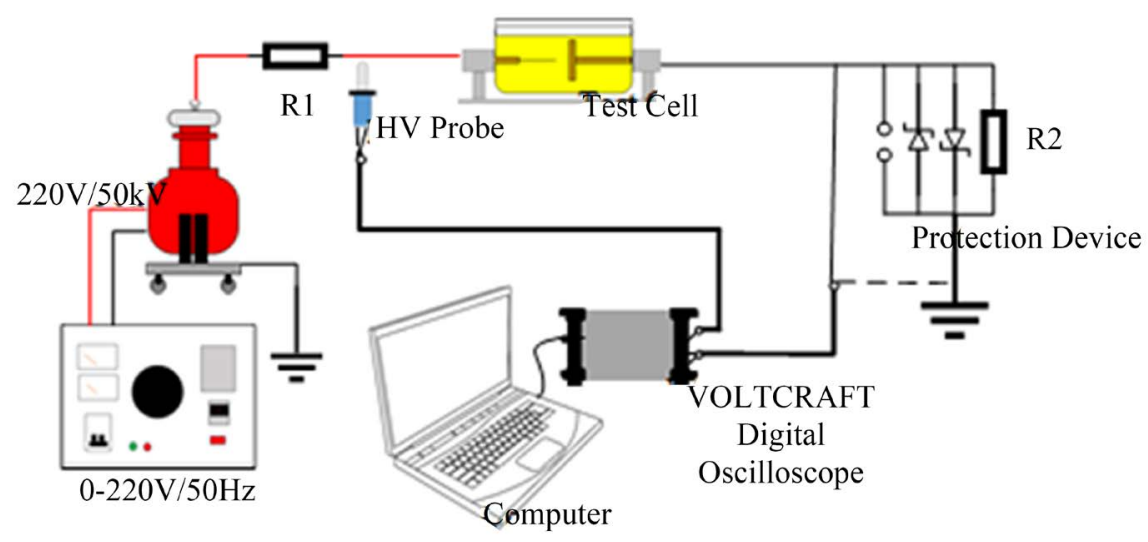

Figure 8. Partial discharge experimental setup.

The electrode system used is a point-plan configuration. The electrodes are held horizontally by copper rods $9 \mathrm{~mm}$ in diameter. The tip electrode is a 100/16 organ type industrial needle made of titanium chromium nitride with a tip radius of $5 \mu \mathrm{m}$.

The tip electrode is connected to a dry transformer of $220 \mathrm{~V} / 50 \mathrm{kV}(50 \mathrm{~Hz})$ via a limiting resistor $\mathrm{R} 1$, while the plan electrode is connected to the ground. TIDP and TPDP are determined using a HV probe. Discharge currents are given by measuring the potential drop on a non-inductive resistor R2 in series with the test cell. A protective device consisting of Zener diodes mounted in antiparallel and a spark gap protect the input of the oscilloscope against overcurrent and overvoltage. Partial discharge characteristics are recorded using a Voltcraft USB DSO-2020 memory oscilloscope. Table 2 shows components characteristics of the experimental setup.

The electric field at the tip of the needle is given by [17]:

$$
E=U \cdot \frac{2}{r \cdot \ln (1+4 d / r)}
$$

The TIDP and TPDP measurements were performed according to the procedure proposed by Azcarraga et al. [17] based on IEC 61294 standard.

\section{Results and Discussion}

\subsection{Extraction}

Figure 9 shows visual examination for the different investigated extraction method. There is a difference in the color of the oil depending on the methods. The oil obtained by method $\mathrm{C}$ is the lightest, while that obtained by method $\mathrm{A}$ is the darkest. Crude castor oil obtained by Method A is not suitable for dielectric application and treatment could be very difficult. It can therefore be concluded that the preheating temperature has an effect on the quality of the oil. The cold-pressed shelled seeds give a better quality of the oil.

Table 3 examines a comparative study of the return for each method. The yield of Method A is the lowest. By comparing method B and D, it found that 
Table 2. Characteristics of experimental setup components of partial discharges.

\begin{tabular}{cccc}
\hline \multirow{2}{*}{ Characteristic } & \multicolumn{3}{c}{ Circuit Components } \\
\cline { 2 - 4 } & R1 & R2 & HV Probe \\
\hline Resistance Value $(\Omega)$ & $10^{8}$ & 50 & - \\
Power $(\mathrm{W})$ & 2 & 0.25 & - \\
Ratio & - & - & $1000: 1$ \\
Precison & - & - & $\pm 5 \%$ \\
\hline
\end{tabular}

Table 3. Comparison of extraction methods.

\begin{tabular}{cccccc}
\hline \multirow{2}{*}{ Method } & \multicolumn{5}{c}{ Properties } \\
\cline { 2 - 6 } & $\begin{array}{c}\text { Weight of } \\
\text { seeds }(\mathrm{g})\end{array}$ & $\begin{array}{c}\text { Volume of } \\
\text { crude oil }(\mathrm{ml})\end{array}$ & Extraction rate Oil appearance & $\begin{array}{c}\text { Time of implementation } \\
\text { for 300 ml of COME }\end{array}$ \\
\hline A & 1005 & 99.48 & 09.5 & Dark Brown & 15 hours \\
B & 1001 & 288.08 & 27.8 & Brown & 6 hours \\
C & 1000 & 298.45 & 28.8 & Bright Yellow & 5 days \\
D & 1000 & 248.71 & 24 & Bright Yellow & 4 hours \\
\hline
\end{tabular}

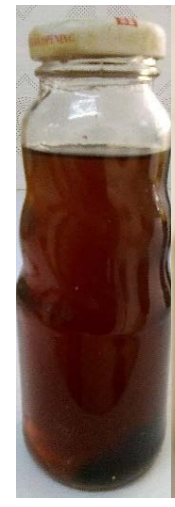

(a)

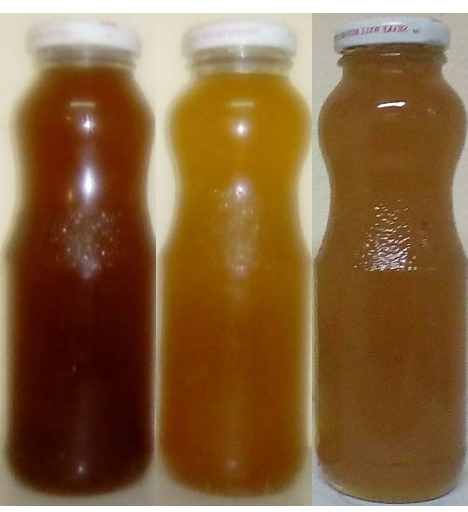

(b)

(d)

Figure 9. Crude castor oil. (a) Method A; (b) Method B; (c) Method C; (d) Method D.

preheating increase the extraction rate. A comparison between $\mathrm{C}$ and $\mathrm{D}$ methods shows that shelling has improved the extraction rate.

However, other parameters taken into account are the time of implementation, from the treatment of the seeds until the obtaining of the crude oil. Method $\mathrm{C}$ has a longer application time (5 days to obtain $300 \mathrm{ml}$ of crude castor oil) due to manual husking of the seeds. Method D is the fastest.

The choice of the method tends to take into account not only the quality of the oil but also the time of execution and the yield obtained. Method $\mathrm{C}$ gives better oil quality and better performance. However, its implementation is very long. Method D will be chosen for further work. It has a yield and oil quality close to the previous one but with much shorter run time.

\subsection{Physicochemical Characterization}

Processed Castor Oil (PCO) were obtained after the extraction, refining and 
transesterification steps. A visual examination can be made from Figure 10.

Table 4 presents a comparative study of the physicochemical characterization of PCO with ASTM D6871 and other transformer vegetable oils. Processing has improved the appearance of $\mathrm{CCO}$ and reduced the value of the Acid Number and viscosity. However, AN is not yet satisfactory under the standard which suggests an additional neutralization. PCO has properties similar to those of the oils in the literature.

\subsection{Dielectric Strength}

IEC 60156 defines the number of consecutive breakdowns at 6 [16]. The dielectric performance is then done by just comparing the means of breakdown voltages. This method of confrontation is imprecise and is subject to many errors, due to the fact that several breakdowns can appear around this average. Several authors have therefore used parametric and nonparametric statistical techniques, more viable, to describe the probability of breakdown of the insulating oil [21] [22] [23] [24]. The breakdown voltage of a dielectric material is a statistically distributed quantity that strongly depends on physicochemical characteristics and impurities present in the oil. It corresponds to a probability of failure. The breakdown is therefore a random phenomenon. It is therefore essential to test its reproducibility. Table 5 shows the analysis of the results of the PCO dielectric strength tests. The average dielectric strength is evaluated at $74.67 \mathrm{kV} / 2.5$ $\mathrm{mm}$ with a standard deviation of $8.04 \mathrm{kV}$. This result meets the prerequisites for an insulating vegetable oil according to IEC 62770 [25], which sets the minimum at $35 \mathrm{kV} / 2.5 \mathrm{~mm}$. The Weibull parameters of the AC dielectric strength of the PCO samples are shown in Table 6. The Characteristic Dielectric Strength $\alpha$ and the shape parameter are calculated with their 95\% confidence intervals. Coefficient relation $\mathrm{R}^{2}=0.983$ stipulates that there is a strong linear relationship between the Weibull parameters. The low values for the shape parameter $\beta$, demonstrate that the probability of breakdown of samples above the mean is higher.

Weibull distribution for PCO samples is plotted in Figure 11.

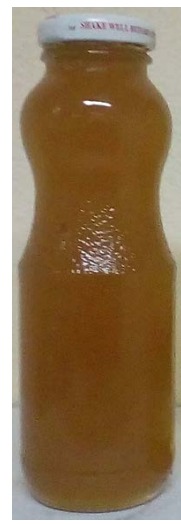

(a)

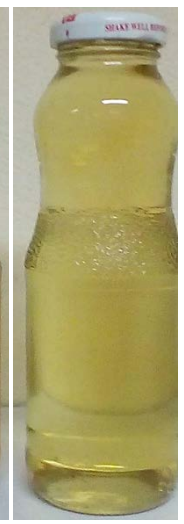

(b)

Figure 10. (a) Crude castor oil and (b) Processed castor oil. 
Table 4. Comparison of physicochemical properties of bio based transformer oils.

\begin{tabular}{cccccccc}
\hline $\begin{array}{c}\text { Physicochemical } \\
\text { properties }\end{array}$ & Unit & ASTM D6871 & \multicolumn{5}{c}{ Properties } \\
\cline { 4 - 8 } Color & - & - & Bright Yellow & Pale Yellow & Pale Yellow & - & Light Green \\
Relative Density at $20^{\circ} \mathrm{C}$ & & $\leq 0.96$ & 0.965 & 0.956 & 0.864 & 0.91 & 0.91 \\
Viscosity at $40^{\circ} \mathrm{C}$ & $\mathrm{cSt}$ & $\leq 50$ & 272.65 & 18.42 & 4.46 & 49.81 & 34.1 \\
Acide Number & $\mathrm{mg} \mathrm{KOH} / \mathrm{g}$ & $\leq 0.06$ & 2.03 & 0.1 & 2,4 & 0.05 & 0.04 \\
\hline
\end{tabular}

${ }^{(a)}$ PKME: Palm Kernel Methyl Ester.

Table 5. Normal distribution parameters for breakdown test.

\begin{tabular}{cccc}
\hline \multirow{3}{*}{ Sample } & \multicolumn{3}{c}{ Parameters } \\
\cline { 2 - 4 } & Number of Breakdowns & $\begin{array}{c}\text { Dielectric Strength } \\
(\mathrm{kV} / 2.5 \mathrm{~mm})\end{array}$ & $\begin{array}{c}\text { Standard Deviation } \\
(\mathrm{kV} / 2.5 \mathrm{~mm})\end{array}$ \\
\hline PCO & 40 & 74.67 & 8.04 \\
\hline
\end{tabular}

Table 6. Weibull parameters for breakdown test.

\begin{tabular}{cccc}
\hline \multirow{2}{*}{ Sample } & \multicolumn{3}{c}{ Weibull Parameters } \\
\cline { 2 - 4 } & \multicolumn{4}{c}{ Characteristic value, $\alpha(\mathrm{kV} / 2.5 \mathrm{~mm})$} & Shape parameter, $\beta$ & Correlation Coefficient \\
\hline \multirow{2}{*}{ PCO } & 78.1 & 11.24 & 0.983 \\
\hline
\end{tabular}

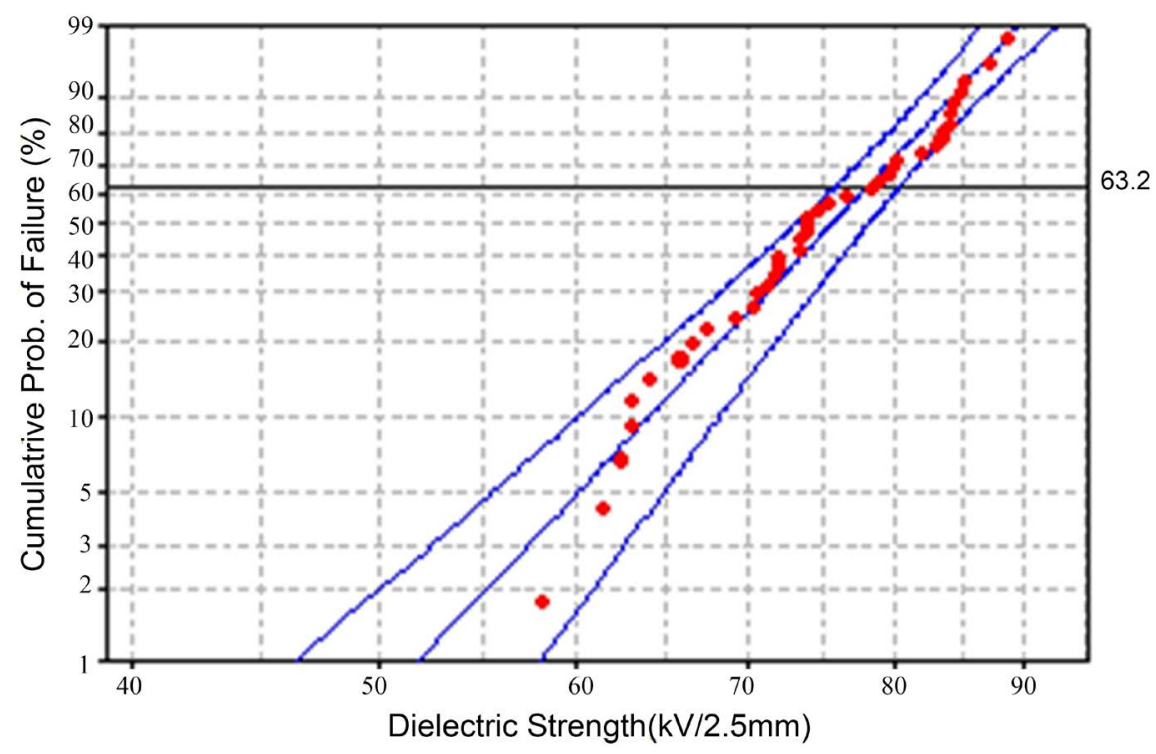

Figure 11. Weibull plot with 95\% confidence intervals of dielectric strength.

\subsection{Partial Discharges}

PDIV and PDPD are used to determine the safety and conduction thresholds of PCO samples in an inhomogeneous electric field. The investigation is carried out at ambient temperature $\left(30^{\circ} \mathrm{C}\right)$ and at atmospheric pressure. Normal distribution parameters is presented in Table 7. Figure 12 illustrates the Weibull distributions with 95\% confidence intervals of PDIV and PDPV. Weibull parameters 
Table 7. Normal distribution parameters for partial discharge tests.

\begin{tabular}{lcc}
\hline & \multicolumn{2}{c}{ Statistic Parameters } \\
\cline { 2 - 3 } & Mean & Std Deviation \\
\hline PDIV $(\mathrm{kV})$ & 29.67 & 0.81 \\
$\operatorname{PDPV}(\mathrm{kV})$ & 30.77 & 0.48 \\
\hline
\end{tabular}

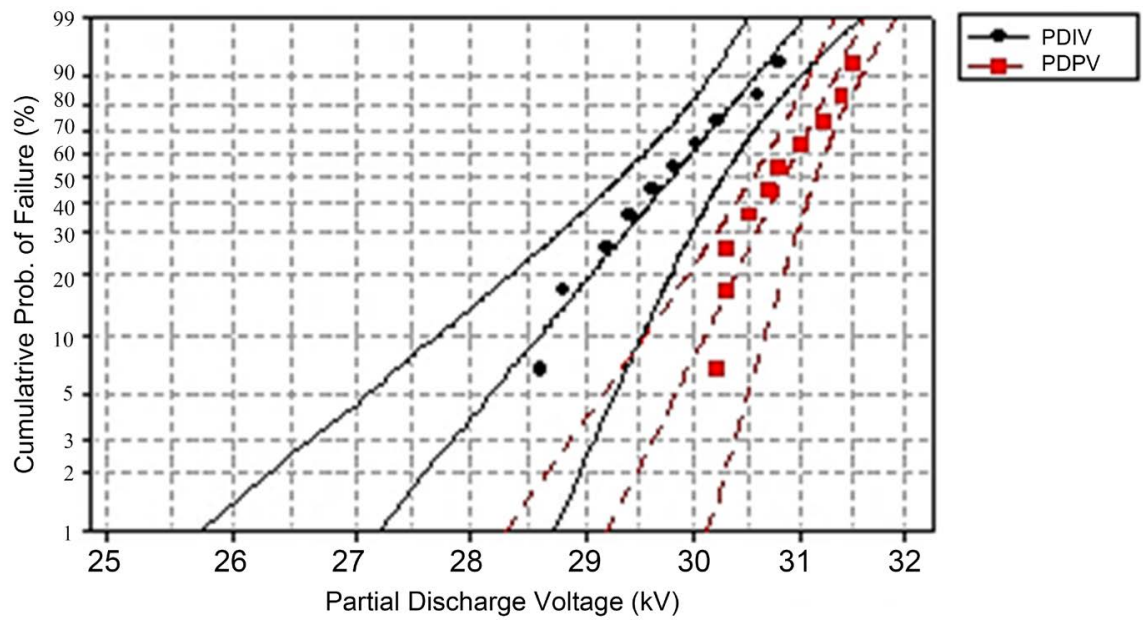

Figure 12. PDIV and PDPV Weibull distributions with 95\% confidence intervals.

are presented in Table 8. The results show that tests adhere to the Weibull distributions.

Partial Discharge Inception Fields (PDIF) are shown in Table 9. There is a significant gap between PDIF and PDPF in PCO. This confers a good level of isolation of the COME subjected to strongly divergent electric fields. The relative change (RC) for COME sample is $3.67 \%$. RC allows to analyze the behavior of the partial discharge activity range occurring in PCO. It provides information on the tendency of insulating oil samples to regenerate to prevent spontaneous breakdown. The lower the RC, the faster the oil is likely to be ionized and then fail. In addition, PDIF of PCO is lower than that of mineral oil.

\section{Conclusion}

This paper focuses on the development of a bio-based insulating fluid and the physicochemical and dielectric characterization of castor oil produced in Cameroon for use as an insulating oil for power transformers. Castor oil cold extracted from unshelled seeds was chosen as the most practical for industrial applications, with an oil yield of $28.8 \%$. The castor oil obtained is bright yellow. A refining and transesterification process has been proposed. Processed castor oil has a pale yellow color, a density of 0.956 , a viscosity of 18.42 cSt and an acid value of $0.1 \mathrm{mg} \mathrm{KOH} / \mathrm{g}$. Its physicochemical characteristics are similar to those of approved oils. Excluding the acidity, the physicochemical properties comply with the specifications of the ASTM D6871 standard. The dielectric strength is $74.67 \mathrm{kV} / 2.5 \mathrm{~mm}$ and complies with the IEC 62770 standard. Moreover, the 
Table 8. Weibull parameters for partial discharges tests.

\begin{tabular}{cccc}
\hline \multirow{2}{*}{ Sample } & \multicolumn{3}{c}{ Weibull Parameters } \\
\cline { 2 - 4 } & Characteristic value, $\alpha(\mathrm{kV} / 2.5 \mathrm{~mm})$ & Shape parameter, $\beta$ & Correlation Coefficient \\
\hline PDIV & 30.02 & 46.43 & 0.983 \\
PDPV & 30.98 & 81.29 & 0.951 \\
\hline
\end{tabular}

Table 9. Partial discharge fields of PCO and comparison with mineral oil.

\begin{tabular}{cccc}
\hline \multirow{2}{*}{ Samples } & \multicolumn{3}{c}{ Partial Discharge Inception and Propagation Fields } \\
\cline { 2 - 4 } & PDIF $(\mathrm{kV} / \mathrm{mm})$ & $\mathrm{PDPF}(\mathrm{kV} / \mathrm{mm})$ & $\mathrm{RC}(\%)$ \\
\hline PCO & 224.01 & 232.23 & 3,67 \\
Mineral Oil [17] & 420 & - & - \\
\hline
\end{tabular}

statistical analysis proves the dielectric strength of the castor oil treated follows a Weibull law. Similarly, the value of PDIV is $29.67 \mathrm{kV}$. In conclusion, processed castor oil is an excellent candidate for replacing mineral oils in power transformers. However, it is still necessary to understand the impact of the degradation factors on the performance of the Processed Castor Oil.

\section{Acknowledgements}

The authors wish to express their sincere thanks to Prof. Anatole Guy BlaiseAzebaze and Prof. Jean Claude Ndom of Laboratory of Bio-Organic, Analytical, Structural and Materials Chemistry of the University of Douala for their valuable and constructive suggestions during the planning and development of this research work. Special thanks to Mr. Richard Daris Nguedap for his help with chemical techniques and comments that added value to the writing of this paper.

\section{Conflicts of Interest}

The authors declare no conflicts of interest regarding the publication of this paper.

\section{References}

[1] Mengounou, G.M. and Imano, A.M. (2016) Effect of Processing on Dielectric Strength of Palm Kernel Methyl Esters. Afrique Science, 12, 157-165.

[2] Sitorus, H.B., Beroual, A., Setiabudy, R. and Bismo, S. (2014) Dielectric Strength of Vegetable Oil Based on Jatropha Curcas as a Substitute for Mineral Oil in High Voltage Electrical Equipment. Symposium de Génie Electrique, Cachan, 8-10 July 2014, 1-5. [In French]

[3] Oommen, T. (2002) Vegetable Oils for Liquid-Filled Transformers. IEEE Electrical Insulation Magazine, 18, 6-11. https://doi.org/10.1109/57.981322

[4] Radhika, R., Iruthayarajan, M.W. and Pakianathan, P.S. (2014) Investigation of Critical Parameters of Mixed Insulating Fluids. International Conference on Circuits, Power and Computing Technologies, Nagercoil, 20-21 March 2014, 357-362. https://doi.org/10.1109/ICCPCT.2014.7054754 
[5] Rafiq, M., Lv, Y., Zhou, Y., Ma, K., Wang, W., Li, C. and Wang, Q. (2015) Use of Vegetable Oils as Transformer Oils-A Review. Renewable and Sustainable Energy Reviews, 52, 308-324. https://doi.org/10.1016/j.rser.2015.07.032

[6] Abdelmalik, A. (2014) Chemically Modified Palm Kernel Oil Ester: A Possible Sustainable Alternative Insulating Fluid. Sustainable Materials and Technologies, 1, 42-51. https://doi.org/10.1016/j.susmat.2014.06.001

[7] Sitorus, H.B., Beroual, A., Setiabudy, R. and Bismo, S. (2015) Pre-Breakdown Phenomena in New Vegetable Oil-Based Jatropha curcas Seeds as Substitute of Mineral Oil in High Voltage Equipment. IEEE Transactions on Dielectrics and Electrical Insulation, 22, 2442-2448. https://doi.org/10.1109/TDEI.2015.005069

[8] Mengounou, G.M., Imano, A.M. and Vardamides, J.C. (2015) Physicochemical Characterisation of Palm Kernel Oil for Use in Distribution Transformers. Afrique Sciences, 11, 105-114. [In French]

[9] Mariprasath, T. and Kirubakaran, V. (2015) Pongamia pinnata as Alternate Liquid Dielectrics in Distribution Transformer: A Critical Study on the Property of Viscosity. Advances in Energy and Power, 3, 1-7.

[10] Umar, S., Abdelmalik, A. and Sadiq, U. (2018) Synthesis and Characterization of a Potential Bio-Based Dielectric Fluid from Neem Oil Seed. Industrial Crops and Products, 115, 117-123. https://doi.org/10.1016/j.indcrop.2018.02.009

[11] Ravulapalli, S., Kunta, R. and Ramamoorty, M. (2019) Preparation, Characterization and Feasibility Analysis of Methyl Ester of Sesbania Seeds Oil (MESSO) as Alternate Liquid Dielectrics in Distribution Transformers. RSC Advances, 9, 3311-3319. https://doi.org/10.1039/C8RA08378A

[12] Trochain, J. (1930) Le Ricin (Suite). Journal d agriculture traditionnelle et de botanique appliquée, 10, 578-589. https://doi.org/10.3406/jatba.1930.4881

[13] Dubois, J.L. (2016) Arkema: Castor Reactive Seed Crushing Process to Promote Castor Cultivation. In: de María, P.D., Ed., Industrial Biorenewables: A Practical Viewpoint, John Wiley \& Sons, Hoboken, 63-95. https://doi.org/10.1002/9781118843796.ch3

[14] ASTM (2008) ASTM D 6871. Standard Specification for Natural (Vegetable Oil) Ester Fluids Used in Electrical Apparatus.

[15] Hadjadj, Y., Fofana, I., Sabau, J. and Briosso, E. (2015) Assessing Insulating Oil Degradation by Means of Turbidity and UV/VIS Spectrophotometry Measurements. IEEE Transactions on Dielectrics and Electrical Insulation, 22, 2653-2660. https://doi.org/10.1109/TDEI.2015.005111

[16] IEC (2003) IEC 60156: Insulating Liquids-Determination of the Breakdown Voltage at Power Frequency-Test Method. International Electrotechnical Commission, Geneva.

[17] Azcarraga, C., Cavallini, A. and Piovan, U. (2014) A Comparison of the Voltage Withstand Properties of Ester and Mineral Oils. IEEE Electrical Insulation Magazine, 30, 6-14. https://doi.org/10.1109/MEI.2014.6882595

[18] Mengounou, G.M., Imano, A.M. and Vardamides, J. (2016) Physicochemical Properties Analysis of Transesterified Palm Kernel Oil. IUT-ENT 2016, Sciences, Technologies et Développement, Douala, July 2016, 210-212. [In French]

[19] Evangelista Jr., J.M., Coelho, F.E.B., Carvalho, J.A., Araújo, E.M., Miranda, T.L. and Salum, A. (2017) Development of a New Bio-Based Insulating Fluid from Jatropha curcas Oil for Power Transformers. Advances in Chemical Engineering and Science, 7, 235-255. https://doi.org/10.4236/aces.2017.72018 
[20] Yao, S., Li, J., Li, L., Liao, R. and Zhou, J. (2014) Comparison Analysis to Thermal Aging Properties of Vegetable and Mineral Insulating Oils. International Conference on High Voltage Engineering and Application, Poznan, 8-11 September 2014, 1-4. https://doi.org/10.1109/ICHVE.2014.7035397

[21] Rajeswari, R., Chandrasekar, S. and Karthik, B. (2019) Statistical Analysis of Partial

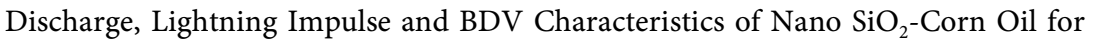
HV Insulation Applications. Journal of Electrical Engineering \& Technology, 14, 877-888. https://doi.org/10.1007/s42835-019-00095-Z

[22] Zhou, Y., Sui, S., Li, J., Wang, Z., Cui, W., Lv, Y. and Li, C. (2018) Statistical Analysis of Moisture's Effect on AC Breakdown Strength of $\mathrm{TiO}_{2}$ Nanofluids. Journal of Molecular Liquids, 249, 420-428.

https://doi.org/10.1016/j.molliq.2017.11.076

[23] Beroual, A., Sitorus, H.B., Setiabudy, R. and Bismo, S. (2018) Comparative Study of AC and DC Breakdown Voltages in Jatropha Methyl Ester Oil, Mineral Oil, and Their Mixtures. IEEE Transactions on Dielectrics and Electrical Insulation, 25, 1831-1836. https://doi.org/10.1109/TDEI.2018.007219

[24] Martin, D. and Wang, Z. (2008) Statistical Analysis of the AC Breakdown Voltages of Ester Based Transformer Oils. IEEE Transactions on Dielectrics and Electrical Insulation, 15, 1044-1050. https://doi.org/10.1109/TDEI.2008.4591226

[25] IEC (2003) IEC 62770. Fluids for Electrotechnical Applications-Unused Natural Esters for Transformers and Similar Electrical Equipment. International Electrotechnical Commission, Geneva. 